\title{
Impact of drought on agriculture in North Karnataka - An economic analysis
}

\section{LAXMI N. TIRLAPUR AND N.R. MAMLE DESAI}

Article Chronicle :

Received:

01.05.2016;

Revised:

04.05.2016;

Accepted :

21.05.2016

\section{Key Words :}

Drought,

Vulnerability,

Livelihood,

Meteorological

drought
ABSTRACT : Agriculture, in India, is strongly affected by two major hydro-meteorological disasters, namely drought and flood. As a result drought is considered as one of the biggest menace to agriculture among all weather related crisis. Keeping this in view present study was carried out to analyse the impact of drought on agriculture in North-Karnataka. Study was based on primary data collected using pretested schedule. Data was analysed using tabular analysis. Results of the study revealed that 97.50 per cent of the responded that drought cause's very high reduction in household income and it causes unemployment. Majority of respondents opinioned that population migration $(37.50 \%)$ and conflicts for water in the society $(18.75 \%)$ was very high due to drought. Drought had very high impact on some of the parameters such as declining in ground water level $(85 \%)$, created water scarcity $(71.25 \%)$, average temperature was increased $(18.75 \%)$ and degraded pasture $(6.25 \%)$. During normal year farmers were able to get 4.39 q, 3.16 q, 3.18 q, 8.28 q, 4.89 q, 3 q, 3.89 q, 10 q, 9.85 q, $4.55 \mathrm{q}$ and $4.62 \mathrm{q}$ of Jowar, Wheat, Bajra, maize, Tur, Greengram, Chickpea, Groundnut, Cotton, Sunflower and Safflower, respectively. But during drought years yield levels of the crops was less. About 74.28 per cent less yield was obtained in case of Bajra followed by 61.34 per cent reduction in Tur yield. In case of Belagavi district, farmers were able to get 53.26 per cent reduction in Jowar yield. Farmers were able to get 15.52 quintal and 12.11 quintals of maize during normal and drought years, respectively. Due to drought farmers were carried out double sowing. About 31.66 per cent and 20 per cent of the respondents were able to carry double sowing in Vijayapura and Belagavi districts, respectively. Majority of the farmers said that in order to overcome the drought they search for alternative source of income $(71.25 \%)$ and store the crops for future consumption (70\%). Other alternative preparative measures adopted by farmers are storing of crop residue for livestock, growing less water consuming crops, selling of some livestock's and migrated for alternative source of employment.

HOW TO CITE THIS ARTICLE : Tirlapur, Laxmi N. and Desai, N.R. Mamle (2016). Impact of drought on agriculture in North Karnataka - An economic analysis. Asian J. Environ. Sci., 11(1): 87-93, DOI: 10.15740/ HAS/AJES/11.1/87-93.

Author for correspondence :

LAXMI N. TIRLAPUR

Department of Agricultural Economics, College of Agriculture, University of Agricultural Sciences, DHARWAD (KARNATAKA) INDIA

Email : laxmint4424@ gmail.com

See end of the article for Coopted authors' 